\title{
Editorial
}

\section{Leadership development and global talent management in the Asian context: An introduction}

Asian Business \& Management (2013) 12,381-386. doi:10.1057/abm.2013.10

The breakneck pace of economic growth in many Asian countries has resulted in a dire shortage of managerial talent. China has recently surpassed Japan as the world's second largest economy (World Bank, 2013); and in total, Asian countries hold 6 of the top 20 positions of total gross domestic product (including China, Japan, India, Australia, Republic of Korea and Indonesia). In addition, 7 of the top 11 economies with the largest foreign reserves in the world hail from Asia (China, Japan, Taiwan, Republic of Korea, Hong Kong, India and Singapore). In short, the economic miracle in many Asian countries has become a double-edged sword - on the one hand, it has catapulted some of the most backward economies into the forefront of the world within a few decades; on the other hand, however, it has resulted in a 'compressed timeframe in which leaders in Asia must be forged' (Conference Board, 2013, p. 4).

According to a 2013 survey of 210 human-capital executives in Asia, only 11 per cent of those polled indicated that they 'have been very successful in identifying and accelerating leadership talent'. Furthermore, the same report found that 'turnover ..., particularly among high performers' was substantially higher than that in other regions of the world (Conference Board, 2013, p. 4). These findings highlight the challenges that confront firms in the Asian region as they seek to attain and/or sustain economic growth and development. As such, Asia continues to be a fertile ground for the examination of leadership development and global talent management.

The role of more established economies such as Japan can be contrasted with recent developing economies to provide an examination of convergent and divergent trends in global talent management in the region. Over a third of Fortune's Global 500 companies are from the Asian region (Tung, 2013), which illustrates the significant economic impact of the region. The economic scope and change in Asia supports the need to examine, understand and put in context issues related to global talent management and leadership within the region (Tung, 2013).

This Special Issue includes five papers that provide perspectives on the issues from different vantage points: from outward investment to direct and indirect control of firms, identification of managerial competencies and approaches to leadership development. A couple of dominant perspectives have emerged from recent studies 
on Asia, both providing support for the continuing debate on whether human resource management development and practices are converging or diverging. The papers in this issue collectively present findings with respect to this debate. Interestingly, Tung (2013) reinforces the perspective that 'either/or' may not be the proper focus, but that we should focus more on the 'and' of convergent and divergent perspectives, thus allowing for a richer approach to contextualization analysis of the Asian context. Even though we use the term 'Asia', we must caution against the fallacious assumption that all Asian countries are more or less similar. There is a lot of diversity across Asian countries - such as between China and India and even among China, Japan and Korea, three countries influenced by Confucianism. Furthermore, significant intranational diversity exists within each of the countries (Tung et al, 2008; Tung and Verbeke, 2010).

With the aforementioned caveat, the papers in this Special Issue, as a whole, focus on fundamental issues about leadership and global talent management in the Asian context. For instance, a most basic question is what management competencies/skills and experience are related to organizational functioning, internationalization and alignment?

The Boermans and Roelfsema (2013) study is one of the first empirical studies to examine the role of leadership resource (in terms of experience and educational attainment) in a firm's internationalization in the Indian context. They found that managerial capabilities perform a significant role in the internationalization of Indian firms. International work experience in multinational firms before individuals' current jobs in Indian firms was related to whether or not the firm was involved in exports, a low-commitment mode of internationalization. Higher commitment modes, for example, foreign direct investment (FDI), is related to whether or not senior management had foreign business education. They argue that international work experience and business education enhance the firm's absorptive capability, establish network linkages, facilitate the exchange of research and development knowledge, and enhance management's understanding of the global business environment. Whereas the insights garnered on a firm's decision to export or enter into FDI in this study do not replace the other determinants/drivers of FDI posited by Dunning (2000), for example, the findings of Boermans and Roelfsema do highlight the importance of social networks (Granovetter, 1985) and the resource-based view of competitive advantage (Barney, 2001) in a firm's internationalization process.

The relationship between international experience and exporting in Boermans and Roelfsema (2013) is an important contrast to the interview evidence presented by Schmidt et al (2013) in their study of Swedish firms. Some of the managers they interviewed indicated a reluctance among Chinese managers to gain international work experience, as they believed that sufficient managerial experience could be gained in China. This finding is somewhat surprising in light of the traditional Chinese attitude toward learning and the fact that China remains the top supplier country of students in business, engineering and computer science programs in North 
America, Europe and indeed much of the developed world. Although there is ample opportunity for Chinese managers to gain managerial experience within China in light of the sizeable amount of FDI in China and the abundance of Western-style MBA programs in that country, the Chinese in general do place a premium on learning from abroad.

Pudelko and Tenzer (2013) focus on a critical element of alignment within a diversified sample of multinational organizations with home bases in Japan, Germany and the United States and operating in the other two countries. Japanese respondents from the sampled MNCs assigned a higher proportion of expatriates to high subsidiary positions than did the US or German MNCs. The authors assert that issues of control and alignment of global staffing and talent management strategies within the multinational corporations (MNCs) lie at the heart of these differences. In other words, senior management in some countries (Germany and the United States) are more comfortable with reliance on direct control from headquarters and staffing of subsidiaries with local managers, while others, in this case Japanese firms, are more reliant on indirect control through the deployment of expatriates in key management positions. Pudelko and Tenzer further explore the differentiation of control based on functional areas and find that direct control is more common for accounting/finance and production functions, but indirect control differs between the countries for functions such as marketing and human resources. In general, Japanese MNCs tend to exercise significant indirect control over these functions (marketing and human resources), the United States and Germany less so. The finding of less indirect control over marketing and human resources is consistent with the views from expatriate and local managers in studies conducted by other authors (see, for example, Bruning et al, 2011). Pudelko and Tenzer suggest that the replacement of ethnocentric staffing policies with one of mixing managers from the parent, host and third countries according to individual strengths may allow Japanese MNCs to substantially increase their ability to achieve learning, innovation and corporate integration (see also Collings and Scullion, 2012).

The study by Bosch et al (2013) focuses on validating a leadership competency model developed by Cardona and Garcia (2005) in a select sample of Asian countries and comparing the results with a non-Asian sample of countries. The paper examines whether managerial competencies (external, interpersonal and personal) are stable across Asian and non-Asian countries. While there was evidence of factor stability in the model, subordinates of managers in Asian countries tend to place a heavier emphasis on the external and interpersonal dimensions, whereas their counterparts in non-Asian countries, in general, tend to focus more on the personal dimension. Identification of competencies that are generalizable across countries provides a convergent focus for firm management of the development of leadership expertise, which also substantiates the findings of Schmidt et al (2013) that Swedish firms did not find a need to tailor their leadership development strategies to different contexts. 
Van Velsor et al (2013) focus on key learning events of managers in China and India, compared with the United States. Again, convergent observations are most common - the main sources of learning about leadership among Chinese and Indians are similar to reports from managers in the United States. One of the reasons cited is the homogenization effect of large global organizations in terms of the opportunities available for leadership development (and possibly competencies that are highly valued, that is, Bosch et al, 2013). Van Velsor and colleagues also identified national cultural differences in the evaluation of leadership developmental experiences. For example, personal experiences were deemed particularly important for Indian managers. Furthermore, Van Velsor and colleagues propose that mentoring and special assignments be used for developmental purposes for Asian managers. As leadership assignments are seen as key leadership developmental events, the observation by Schmidt et al (2013) is again relevant in this context. The resistance to international assignments by Chinese managers noted by Schmidt and colleagues could work to the detriment of Chinese firms if this attitude were to hold among a larger sample of Chinese managers. The Boermans and Roelfsema (2013) study also points to the importance of international experience and education in talent development.

In the interview study by Schmidt et al (2013), they present a case for standardization of various selection and development practices in Swedish firms operating in China. Through interviews, they examine how a number of Swedish firms transfer or develop a coherent organizational culture through their leadership selection and training practices. In essence, they find that the companies did not report significant obstacles in transferring their talent management and leadership development approaches to the Chinese context, nor did they tailor their approaches significantly to account for cultural differences in China. Some evidence was found for tailoring the talent management processes at lower levels of the organization, but not at higher levels.

Returning to the convergence and divergence debate, as a group, the authors in this Special Issue present evidence in favor of a convergence trend driven by education and international work experience (Boermans and Roelfsema), the pursuit of alignment in MNCs (Pudelko and Tenzer, 2013; Schmidt et al, 2013; Van Velsor et al, 2013) and basic competencies valued and shared across cultural contexts (Bosch et al, 2013). There is some evidence of simultaneous divergence, for example, more weight on certain managerial competencies (Bosch et al, 2013), minimal cultural differences in control and alignment strategies in organizations (Pudelko and Tenzer, 2013), leadership development strategies (Van Velsor et al, 2013) and hierarchical differences in the adoption of standardized approaches to leadership talent management (Schmidt et al, 2013); however, the overall message is one of similarity rather than large differences in what is valued as leadership competencies, how leaders are selected and trained, and the alignment processes in multinational organizations. These findings are, by and large, consistent with those found in the Conference Board Report (2013). 
That convergence appears to outweigh divergence is not surprising in the light of globalization, where the ability to attain and sustain international competitiveness necessitates that firms everywhere emulate best practices and principles wherever they can be found. However, the fact that practices continue to diverge across countries support Ralston's (2008) concept of crossvergence and the need for researchers and practitioners alike to polycontextualize (Von Glinow et al, 2004) to ensure that best practices developed in one context can be fruitfully applied to a different set of conditions elsewhere.

\section{References}

Barney, J.B. (2001) Resource-based theories of competitive advantage: A ten-year retrospective on the resource-based view. Journal of Management 27(1): 643-650.

Boermans, M.A. and Roelfsema, H. (2013) The effects of managerial capabilities on export, FDI and innovation: Evidence from Indian firms. Asian Business and Management 12(4): 387-408.

Bosch, M.J., Lee, Y.-T. and Cardona, P. (2013) Multicultural validation of a three-dimensional framework of managerial competencies: A comparative analysis of its application in Asian versus non-Asian countries. Asian Business and Management 12(4): 433-453.

Bruning, N.S., Bebenroth, R. and Pascha, W. (2011) Valuing Japan-based German expatriate and local managers' functions: Do subsidiary age and managerial perspectives matter? International Journal of Human Resource Management 22(4): 778-806.

Cardona, P. and Garcia, P. (2005) How to Develop Leadership Competences. Pamplona, Spain: Eunsa.

Collings, D.G. and Scullion, H. (2012) Global staffing. In: G.K. Stahl, I. Björkman and S. Morris (eds.) Handbook of Research in International Human Resource Management. 2nd edn. Cheltenham, UK: Edward Elgar, pp. 142-161.

Conference Board. (2013) Fast track: Accelerating the leadership development of high potentials in Asia. http://www.conferenceboard.ca/e-library/abstract.aspx?did=5552\&utm_source=elibraryrss \&utm_medium=rss\&utm_campaign=elibrary, accessed 9 June 2013.

Dunning, J.H. (2000) The eclectic paradigm as an envelope for economic and business theories of MNE activity. International Business Review 9(2): 163-190.

Granovetter, M. (1985) Economic action and social structure: The problem of embeddedness. American Journal of Sociology 91(3): 481-510.

Pudelko, M. and Tenzer, H. (2013) Subsidiary control in Japanese, German and US multinational corporations: Direct control from headquarters versus indirect control through expatriation. Asian Business and Management 12(4): 409-431.

Ralston, D.A. (2008) The crossvergence perspective: Reflections and projects. Journal of International Business Studies 39(1): 27-40.

Schmidt, C., Mansson, S. and Dolles, H. (2013) Managing talents for global leadership positions in MNCs: Responding to the challenges in China. Asian Business and Management 12(4): 477-496.

Tung, R.L. (2013) The future of East Asian management. In: M. Warner (ed.) Managing across Diverse Cultures in East Asia. London: Routledge, pp. 263-276.

Tung, R.L., Worm, V. and Fang, T. (2008) Sino-Western business negotiations revisited - 30 years after China's open-door policy. Organizational Dynamics 37(1): 60-74.

Tung, R.L. and Verbeke, A. (2010) Beyond Hofstede and GLOBE: Improving the quality of cross-cultural research. Journal of International Business Studies 41(8): 1259-1274.

Van Velsor, E., Wilson, M., Criswell, C. and Chandrasekar, N.A. (2013) Learning to lead: A comparison of developmental events and learning among managers in China, India and the U.S. Asian Business and Management 12(4): 455-476. 
Von Glinow, M.A., Shapiro, D.L. and Brett, J.M. (2004) Can we talk, and should we? Managing emotional conflict in multicultural teams. Academy of Management Review 29(4): 578-592.

World Bank. (2013) Gross domestic product 2011. http://databank.worldbank.org/data/download/GDP. pdf (updated 15 April 2013), accessed 9 June 2013.

Nealia S. Bruning

I.H. Asper School of Business, University of Manitoba, Winnipeg, Canada.

E-mail: sue.bruning@ad.umanitoba.ca

Rosalie L. Tung Beedie School of Business, Simon Fraser University, Burnaby, Canada.

E-mail: tung@ @fu.ca 